\title{
BMJ Open Influence of work-related psychosocial factors on the prevalence of chronic pain and quality of life in patients with chronic pain
}

\author{
Keiko Yamada, ${ }^{1}$ Ko Matsudaira, ${ }^{2,3}$ Hironori Imano, ${ }^{1}$ Akihiko Kitamura, ${ }^{1}$ \\ Hiroyasu Iso ${ }^{1}$
}

To cite: Yamada $\mathrm{K}$, Matsudaira $\mathrm{K}$, Imano $\mathrm{H}$, et al. Influence of work-related psychosocial factors on the prevalence of chronic pain and quality of life in patients with chronic pain. BMJ Open 2016;6: 010356 . doi:10.1136/bmjopen-2015010356

- Prepublication history for this paper is available online To view these files please visit the journal online (http://dx.doi.org/10.1136/ bmjopen-2015-010356).

Received 23 October 2015 Accepted 23 March 2016

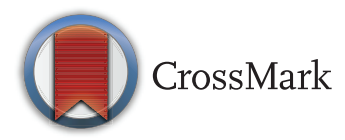

${ }^{1}$ Department of Public Health and Social Medicine, Osaka University Graduate School of Medicine, Suita-shi, Osaka, Japan

${ }^{2}$ Faculty of Medicine, Department of Medical Research and Management for Musculoskeletal Pain, 22nd Century Medical and Research Center, The University of Tokyo, Tokyo, Japan

${ }^{3}$ Japan Labour Health and Welfare Organization, Tokyo, Japan

Correspondence to Dr Hiroyasu Iso; iso@pbhel.med.osaka-u.ac.jp

\section{ABSTRACT}

Objectives: Working is a common cause of chronic pain for workers. However, most of them need to continue working despite the pain in order to make a living unless they get a sick leave or retirement. We hypothesised that the therapeutic effect of vocational rehabilitation may depend on psychosocial factors related to the workplace. To test this hypothesis, we examined the association of work-related psychosocial factors with the prevalence of chronic pain or healthrelated quality of life (HRQoL) among workers with chronic pain.

Methods: We examined 1764 workers aged 20-59 years in the pain-associated cross-sectional epidemiological survey in Japan. The outcomes were (1) chronic pain prevalence among all workers and (2) low Euro QoL (EQ-5D $<0.76$; mean value of the current study) prevalence among workers with chronic pain according to the degree of workplace social support and job satisfaction. Workplace social support and job satisfaction were measured using the Brief Job Stress Questionnaire. Multivariable-adjusted ORs were calculated using a logistic regression model including age, sex, smoking, exercise, sleep time, work hours, body mass index, personal consumption expenditure, intensity of pain and the presence of severe depressive symptoms.

Results: Chronic pain prevalence was higher among males reporting job dissatisfaction compared with those reporting job satisfaction. No difference was observed among women. Chronic pain prevalence did not differ between workers of either sex reporting poor workplace social support compared with those reporting sufficient support. Among workers with chronic pain, low HRQoL was more frequent in those reporting job dissatisfaction. Similarly, low HRQoL was more frequent in patients with chronic pain reporting poor social support from supervisors or co-workers compared with patients reporting sufficient support.

Conclusions: Work-related psychosocial factors are critical for HRQoL in patients with chronic pain.

\section{INTRODUCTION}

The existence of chronic pain among workers is an economic burden and major public

\section{Strengths and limitations of this study}

- Our study included a large population and used the specialised questionnaire for pain medicine.

- This is the first study to investigate the association between work-related psychosocial factors and health-related quality of life of patients with chronic pain.

- Our questionnaire included only three psychosocial factors: social support from supervisors, support from co-workers and job satisfaction.

- Patients with severe chronic pain who took sick leave or had retired because of pain were not included in our study.

health problem. ${ }^{1}$ Although most workers need to continue their work despite pain, in order to make a living, unless they get sick leave or retire, workers with chronic pain are likely to have lower productivity. Physical and mental overwork can cause chronic pain, which, according to the classical rehabilitation model, requires rest for relief and remission. $^{2}$ In contrast, the recent vocational rehabilitation model recommends continuing work or prompt return as soon as possible based on studies showing the benefits of remaining active despite pain. ${ }^{2-4}$ However, patients with chronic pain may require added motivation or appropriate accommodation; thus, success of vocational rehabilitation may depend on psychosocial factors related to the workplace environment.

Poor work-related psychosocial factors were associated with a higher chronic pain prevalence among European and North American workers, ${ }^{2}{ }^{56}$ but these relationships have not been examined among Asian workers. Workplace environments vary among cultures; therefore, the influence of psychosocial factors on chronic pain may also differ in Asia. ${ }^{7}$ 
Health-related quality of life (HRQoL) measures are frequently used in epidemiology to quantify general health and functional status. Furthermore, HRQoL has been associated with worker productivity and is often used to calculate the cost-effectiveness of healthcare programmes. ${ }^{8}$ Thus, HRQoL is an appropriate metric to evaluate the effects of work-related psychosocial factors on workers with health problems, but the relationship between work-related psychosocial factors and HRQoL of patients with chronic pain has not been explored.

Thus, we analysed the association between workrelated psychosocial factors and chronic pain prevalence in the Japanese workplace. In addition, we examined the association between work-related psychosocial factors and HRQoL among patients with chronic pain.

\section{MATERIALS AND METHODS \\ Study population}

The pain-associated cross-sectional epidemiological study was an internet survey (conducted from 10 to 18 January 2009) designed to evaluate pain in a large Japanese population, using a self-reported questionnaire. ${ }^{9}$ The sampling procedure ending in the sample being analysed in the current study is shown in figure 1. A total of 20044 respondents (9746 men and 10298 women) aged 2079 years, matching the Japanese demographic composition in $2007,{ }^{10}$ were recruited by email from 1477585 candidates who registered with an internet survey company (Rakuten Research Inc, Tokyo, Japan). ${ }^{11}$ Invitation emails containing a link to the first questionnaire were sent by computer system until the targeted sample number was achieved. Incomplete questionnaires were rejected automatically, so the response rate was not calculated. The first questionnaire included items on age, sex, job, HRQoL and pain. Subsequently, detailed questionnaires about lifestyle and psychosocial factors were sent to 5000 respondents aged 20-79 years who answered the first questionnaire, 2500 reporting pain and 2500 with no pain. The profile of these 5000 respondents was consistent with the Japanese demographic composition for sex and age in $2007 .{ }^{10}$ A total of 2480 workers aged 20-59 years responded to the second questionnaire and 716 workers who had acute or subacute pain were excluded from our analyses. Thus, we included the data on 1764 workers aged $20-59$ years, 532 with chronic pain and 1232 with no pain, in the analyses.

The proportions for the different job categories were $29.5 \%$ specialists, $8.6 \%$ managers, $28.2 \%$ white-collar workers, $8.4 \%$ sales workers, $3.3 \%$ service workers, $0.6 \%$ primary sector workers, $2.2 \%$ transportation or communication workers, $6.0 \%$ menial labourers, and $13.2 \%$ others. The majority, $86.2 \%$, were full time while $13.8 \%$ were part time.

\section{Ethics}

All participants had given their informed consent before responding to the questionnaire. A credit point for internet shopping was given as an incentive to the respondents.

\section{Measures}

Job satisfaction and social support from supervisors and co-workers were measured using subscales of the Brief Job Stress Questionnaire. ${ }^{12}$ The questionnaire section on social support from supervisors and co-workers consisted of three items ('How well do you get along with your supervisors/co-workers?, 'When you experience difficulties, how much do you rely on your supervisors/ co-workers?' and 'How often do you consult your supervisors/co-workers about your private issues/problems?'). Each item was rated on a four-point scale ranging from 1 (sufficient) to 4 (poor), and the total score was calculated by summing the three items for a total score ranging from 3 to 12 points (with lower scores indicating greater levels of support). Subsequently, we calculated the quartiles of scores for social support from supervisors and from co-workers (higher quartile indicating greater level of support) and classified supervisor support as low $(\mathrm{Q} 1,12-10)$, intermediate $(\mathrm{Q} 2,9$; $\mathrm{Q}$, 8-7) or high (Q4, 6-3 points), and co-worker support as low $(\mathrm{Q} 1,12-9)$, intermediate $(\mathrm{Q} 2,8$; Q3, 7-6) or high (Q4, 5-3). Job satisfaction was classified into four categories: dissatisfied, somewhat dissatisfied, relatively satisfied or satisfied.

The primary outcome measure was chronic pain prevalence in the entire cohort. The participants also answered questions related to their own pain such as the pain sites, pain intensity at each site, the site of dominant pain, the duration of dominant pain and disability due to dominant pain. Pain intensities were scored on an 11-point Numerical Rating Scale (NRS) $(0=$ no pain, $10=$ worst pain imaginable). A score $\geq 5$ for the dominant pain site during the past 3 months was defined as chronic pain.

The secondary outcome was the prevalence of low Euro QoL (EQ-5D), defined as below the mean of 0.76 of the present study, in workers with chronic pain according to the NRS. We used the Japanese version of the EQ-5D instrument to measure HRQoL. ${ }^{13}$ The EQ-5D includes five dimensions: mobility, self-care, usual activities, pain or discomfort, and anxiety or depression. Each dimension is divided into three degrees of severity: 1 (no problem), 2 (moderate) and 3 (extreme problems). The five numbers expressing severity on the five dimensions (eg, 11 233, 22112 or 11333 ) are arranged in the order above, generating $3^{5}$ (or 243) different health statuses. The 243 health statuses are then converted into a single index score called the 'utility value' from 0 (dead) to 1 (full health) according to the conversion table for the Japanese EQ-5D. ${ }^{13}$

The presence of severe depressive symptoms was treated as a confounding factor and used as an adjustment variable because depression is strongly associated with psychosocial factors, chronic pain and quality of 


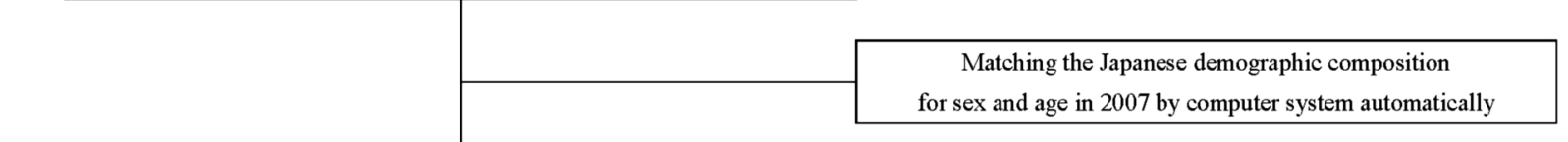

The first questionnaire

20,044 respondents $(9,746$ men and 10,298 women; age, 20-79 years)

716 workers with acute or sub-acute pain were excluded

1,764 workers (age, $20-59$ years)

532 with chronic pain and 1,232 without pain were included in the analyses

Figure 1 Flow chart of the sampling procedure ending in the sample being analysed in the current study.

life. $^{14}$ In the present study, the presence of severe depressive symptoms was defined as a Mental Health Inventory (MHI-5) score $<52 .{ }^{15}$ The MHI-5 is equal to the 36-item Short Form Health Survey (SF-36) 'mental health' domain. ${ }^{16}$ The MHI-5 contains the following five questions: 'How much of the time during the last month have you: (1) been a very nervous person, (2) felt downhearted and blue, (3) felt calm and peaceful, (4) felt so down in the dumps that nothing could cheer you up and (5) been a happy person?' The respondents choose a number from 1 (all of the time) to 6 (none of the time). The score on the MHI-5, ranging from 5 to 30 points, is converted to a 100 -point scale. ${ }^{15} \mathrm{~A}$ previous Japanese study confirmed that the cut point of $<52$ on the MHI-5 (corresponding to $\geq 56$ on the 20-item Zung Self-rating Depression Scale, ZSDS) was useful for screening severe depressive symptoms, with sensitivity of $91.8 \%$ and specificity of $84.6 \% .^{15}$

\section{Statistical analysis}

Analysis of covariance was used to test for differences in age-adjusted means and proportions of the various clinicodemographic characteristics recorded for the analysis. We analysed the association between work-related psychosocial factors and the prevalence of chronic pain among all workers, and the prevalence of low EQ-5D (<the mean of 0.76 ) among workers with chronic pain.

Multivariable-adjusted ORs and 95\% CIs were calculated using the logistic regression model. The adjustment variables included age, sex, smoking status (never-smoker, ex-smoker or current smoker), exercise habit (exercise longer than 30 min more than twice a week; yes or no), sleeping time (hours/day), working hours ( $<40,40$ to 49,50 to 59,60 to 69 or $>70 \mathrm{~h} /$ week), body mass index $\left(\mathrm{kg} / \mathrm{m}^{2}\right.$, categorised in quintiles $)$, personal consumption expenditure (JPY/month) and presence of severe depressive symptoms (MHI-5<53). When we analysed the association between work-related psychosocial factors and the EQ-5D of workers with chronic pain, we further adjusted for pain intensity as expressed on an 11-point NRS ( $0=$ no pain, 10=worst pain imaginable). We could not analyse the data according to job category because the numbers in each were small.

$\mathrm{p}$ Values of $<0.05$ for two-tailed tests were considered statistically significant. All statistical analyses were performed using SAS V.9.4 (SAS Institute Inc, Cary, North Carolina, USA).

\section{RESULTS}

We identified 532 workers aged 20-59 years (309 men and 223 women) who had chronic pain, and 1232 workers (783 men and 449 women) without pain. A total of 306 workers with chronic pain $(57.5 \%)$ reported a severity of 5 points or more on the 11-point NRS for low back pain or neck pain. The prevalence of chronic pain in female workers was significantly higher than in 
male workers $(24.5 \%$ vs $19.7 \%, \mathrm{p}<0.05)$. The prevalence of severe depressive symptoms in patients with chronic pain was $35.3 \%$ for men and $37.2 \%$ for women, about two-times higher than in pain-free workers $(18.1 \%$ for men and $21.4 \%$ for women).

Table 1 shows the age-adjusted means and proportions of clinicodemographic characteristics according to workrelated psychosocial factor category (support from supervisors, support from co-workers, job satisfaction). Workers who received poor support from supervisors and/or co-workers $(\mathrm{Q} 1)$ and were dissatisfied with their jobs demonstrated a higher prevalence of severe depressive symptoms. A greater proportion of male workers who were dissatisfied with their job exhibited short sleep compared to those with good work-related psychosocial factors. Male workers receiving poor support from supervisors and/or co-workers, and who were dissatisfied with their jobs, exhibited a higher prevalence of chronic pain compared with those satisfied with their jobs and receiving sufficient support. Pain intensity of patients with chronic pain did not vary according to work-related psychosocial factor category.

Table 2 shows the age-adjusted and multivariable ORs of chronic pain patient characteristics according to work-related psychosocial factor category. Male workers with poor job satisfaction exhibited a higher prevalence of chronic pain, and the association remained statistically significant after adjustment for confounding factors and the presence of severe depressive symptoms. The degree of social support from supervisors/co-workers was associated with a progressive decrease in the prevalence of chronic pain among male workers. However, after adjustment for confounding variables and presence of severe depressive symptoms, most of these individual associations between chronic pain prevalence and support quartile were no longer statistically significant. No such associations were found for female workers.

Table 3 shows the age-adjusted and multivariable ORs for low EQ-5D (less than the mean of 0.76) in workers with chronic pain. The mean EQ-5D value of all workers was 0.90 (SD 0.14), 0.96 for those without chronic pain (SD 0.09) and 0.76 (SD 0.12) for those with chronic pain; therefore, 0.76 was used as the cut-off point. Work-related social factors were significantly associated with the low EQ-5D (less than the mean of 0.76) among workers of both sexes with chronic pain in the age-adjusted model and model 1. However, those associations were no longer statistically significant in the severe depressive syndrome-adjusted model (model 2), except for the category, support from supervisors/ co-workers for female workers. In the entire cohort of patients with chronic pain (men and women), there was a significantly higher prevalence of low EQ-5D in those reporting poor support from supervisors and from those reporting poor support from co-workers. These associations were statistically significant in neither men nor women separately.

\section{DISCUSSION}

These results reveal a significant association between job dissatisfaction and the prevalence of chronic pain in Japanese male workers, in accord with previous findings of a link between job dissatisfaction and chronic musculoskeletal pain among European and North American workers. ${ }^{256}$ However, no gender differences were found in those studies, while the link between job dissatisfaction and chronic pain was specific to men in the current study.

In general, there are gender differences in pain and analgaesia, ${ }^{17}{ }^{18}$ so we stratified participants by sex. Previous studies have found that women experience chronic pain more often than men. ${ }^{17}{ }^{18}$ Similarly, the prevalence of chronic pain was significantly higher in women than in men in the current study. However, job satisfaction was associated with the prevalence of chronic pain only among men. It was suggested that the incidence of chronic pain may be more influenced by job satisfaction among men than among women in Japan. Men generally work longer hours than do women in Japan, with an average daily working time of $416 \mathrm{~min}$ for men and $290 \mathrm{~min}$ for women in $2011 .{ }^{19}$ On the other hand, many Japanese men do not share housework, averaging only $42 \mathrm{~min}$ daily compared with $215 \mathrm{~min}$ for women. ${ }^{19}$ In our study, the proportion of male workers who had been working $>60 \mathrm{~h}$ per week $(15.5 \%)$ were more than that of female workers $(4.2 \%)$.Thus, women may be more strongly affected by psychosocial factors at home than at work due to shorter working hours or cultural expectations. However, psychosocial factors in private life were not examined in this study, so we could not investigate the reasons for this gender difference in the impact of psychosocial factors on chronic pain.

Several recent studies have recommended that patients with chronic pain should continue to work and not take prolonged leave; ${ }^{2-4}$ however, the success of this vocational rehabilitation model could depend on a favourable work environment. Indeed, support from supervisors and co-workers did have a positive effect on workers with chronic pain according to self-reported HRQoL. Similarly, supportive relationships at work led to better HRQoL of employees with severe mental illness. $^{4}$ This need for supportive supervisors and co-workers may result from a lower resiliency and capacity to cope with stress compared with healthy workers. ${ }^{20}$

We investigated the prevalence of low EQ-5D (defined as below the mean of 0.76) among workers with chronic pain as the secondary outcome of our research. In a Finnish study, the mean EQ-5D of the general population was 0.84 and that of the subpopulation with back pain was $0.74 .^{21}$ This is similar to the mean EQ-5D of Japanese workers in the current study, most of whom suffered from back or neck pain. Thus, EQ-5D appears to reflect impaired QoL resulting from chronic musculoskeletal pain. The EQ-5D can also detect meaningful changes in other clinical conditions. ${ }^{22}$ For instance, 
Table 1 Age-adjusted mean values and proportions of characteristics according to the categories of work-related psychosocial factors among workers aged 20-59 years

\begin{tabular}{|c|c|c|c|c|c|c|c|c|c|c|c|c|}
\hline \multirow{2}{*}{$\begin{array}{l}\text { The quartiles of } \\
\text { scores for social } \\
\text { support } \\
\text { Score; with lower } \\
\text { scores indicating } \\
\text { greater levels of } \\
\text { support }\end{array}$} & \multicolumn{4}{|c|}{ Support from supervisors } & \multicolumn{4}{|c|}{ Support from co-workers } & \multicolumn{4}{|c|}{ Job satisfaction } \\
\hline & $\begin{array}{l}6-3 \\
\text { points }\end{array}$ & $\begin{array}{l}8-7 \\
\text { points }\end{array}$ & 9 points & $\begin{array}{l}12-10 \\
\text { points }\end{array}$ & $\begin{array}{l}5-3 \\
\text { points }\end{array}$ & $\begin{array}{l}7-6 \\
\text { points }\end{array}$ & 8 points & 12-9 points & Satisfied & $\begin{array}{l}\text { Relatively } \\
\text { satisfied }\end{array}$ & $\begin{array}{l}\text { Somewhat } \\
\text { dissatisfied }\end{array}$ & Dissatisfied \\
\hline \multicolumn{13}{|l|}{ Men, $n=1092$} \\
\hline $\mathrm{n}$ & 285 & 332 & 232 & 243 & 200 & 351 & 226 & 315 & 136 & 638 & 234 & 84 \\
\hline Age (years) & $40.0(0.6)$ & $42.7(0.5)$ & $40.3(0.7)$ & $41.2(0.6)$ & $40.6(0.6)$ & $43.0(0.7)$ & $41.4(0.5)$ & $39.6(0.7)$ & $39.6(0.9)$ & $41.6(0.4)$ & $41.1(0.7)$ & $40.4(1.1)$ \\
\hline Current smoker (\%) & 32.2 & 37.3 & 28.4 & 32.5 & 37.0 & 31.6 & 32.3 & 32.7 & 31.6 & 31.3 & 36.8 & 38.1 \\
\hline $\begin{array}{l}\text { Have an exercise } \\
\text { habit (\%) }\end{array}$ & 32.3 & 26.2 & 27.2 & 27.6 & 29 & 29.3 & 27 & 27.6 & 37.5 & 28.2 & 23.9 & 26.2 \\
\hline Short sleep (\%) & 6.0 & 2.7 & 3.0 & 8.2 & 3.5 & 5.1 & 3.5 & 6.3 & 3.7 & 4.4 & 3.8 & $13.1 \dagger$ \\
\hline Overwork (\%) & 14.7 & 12.3 & 14.7 & 20.6 & 13.0 & 13.7 & 19.0 & 15.9 & 11.8 & 14.4 & $19.7^{*}$ & $15.5^{\circ}$ \\
\hline $\begin{array}{l}\text { Body mass index } \\
\geq 25(\%)\end{array}$ & 25.6 & 26.2 & 26.7 & 25.9 & 23.5 & 24.2 & 29.2 & 27.6 & 22.8 & 27.0 & 26.5 & 23.8 \\
\hline $\begin{array}{l}\text { Personal } \\
\text { consumption } \\
\text { expenditure } \\
\text { (×10 000 JPY/ } \\
\text { month) }\end{array}$ & 29.1 & 32.2 & 28.7 & 27.6 & 26.3 & $34.7^{*}$ & 28.6 & 26.7 & 32.8 & 28.8 & 28.9 & 32.6 \\
\hline $\begin{array}{l}\text { Severe depressive } \\
\text { symptoms }(\%)\end{array}$ & 13.7 & 17.2 & $23.3 \dagger$ & $41.6 \ddagger$ & 11.5 & 14.8 & $19.5^{\star}$ & $41.9 \ddagger$ & 8.8 & 13.5 & $38.5 \ddagger$ & $75.0 \ddagger$ \\
\hline $\begin{array}{l}\text { Chronic pain }(\% ; \\
\text { number of } \\
\text { participants with } \\
\text { chronic pain, } \\
n=309)\end{array}$ & $23.5(67)$ & $25.9(86)$ & $30.6(71)$ & $35.0 \dagger(85)$ & $25.0(50)$ & $21.4(75)$ & $30.1(69)$ & $36.5 \dagger(115)$ & $19.9(27)$ & $25.7(164)$ & $32.1^{*}(75)$ & $51.2 \ddagger(43)$ \\
\hline $\begin{array}{l}\text { Intensity of pain of } \\
\text { participants with } \\
\text { chronic pain } \\
\text { (Numerical Rating } \\
\text { Scale) }\end{array}$ & 7.0 & 7.0 & 6.9 & 6.9 & 7.2 & 7.0 & 7.0 & 6.8 & 6.4 & $7.1^{*}$ & 6.9 & 7.0 \\
\hline \multicolumn{13}{|l|}{ Women, $n=672$} \\
\hline $\mathrm{n}$ & 160 & 210 & 110 & 192 & 149 & 215 & 95 & 213 & 74 & 411 & 134 & 53 \\
\hline Age (years) & $38.9(0.7)$ & $38.4(0.9)$ & $40.1(0.7)$ & $40.2(0.8)$ & $38.7(0.7)$ & $40.3(1.0)$ & $39.6(0.7)$ & $40.0(0.8)$ & $40.3(1.2)$ & $39.8(0.5)$ & $38.9(0.9)$ & $37.2(1.4)$ \\
\hline Current smoker (\%) & 19.4 & 21.9 & 21.8 & 17.7 & 22.1 & 22.8 & 18.9 & 16.4 & 20.3 & 19.2 & 20.9 & 24.5 \\
\hline $\begin{array}{l}\text { Have an exercise } \\
\text { habit (\%) }\end{array}$ & 26.9 & 19.5 & 18.2 & 18.8 & 19.5 & 22.3 & 25.3 & 18.3 & 27.0 & 23.6 & 11.9 & 13.2 \\
\hline Short sleep (\%) & 4.4 & 4.3 & 1.8 & 6.3 & 3.3 & 4.2 & 7.4 & 4.2 & 1.4 & 4.1 & $7.5^{\star}$ & 3.8 \\
\hline
\end{tabular}




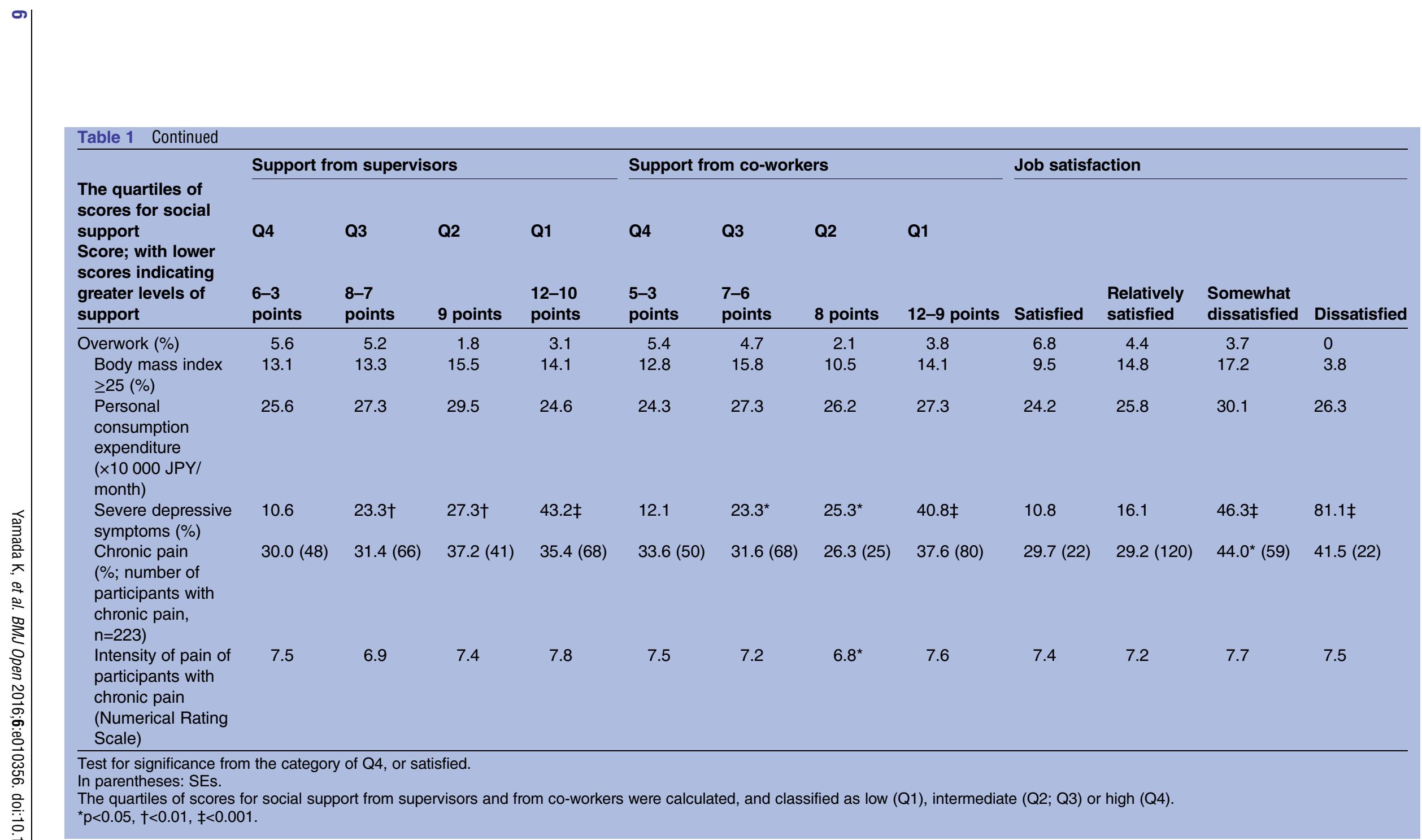


Table 2 ORs (ORs, $95 \% \mathrm{Cl}$ ) of chronic pain according to the categories of work-related psychosocial factors among workers aged 20-59 years

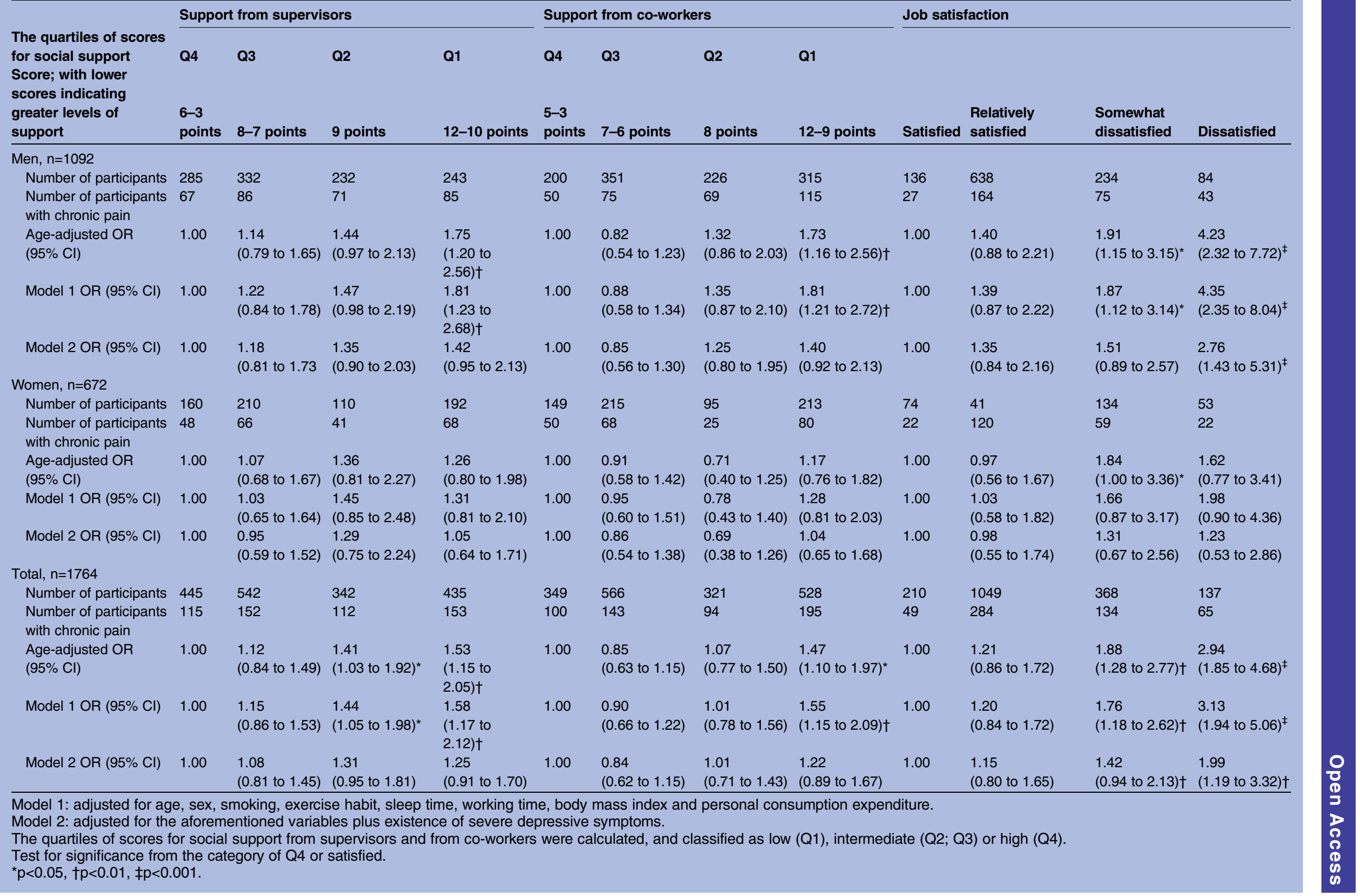




\begin{tabular}{|c|c|c|c|c|c|c|c|c|c|c|c|c|}
\hline \multirow{2}{*}{$\begin{array}{l}\text { The quartiles of } \\
\text { scores } \\
\text { for social support } \\
\text { Score; with lower } \\
\text { scores indicating } \\
\text { greater levels of } \\
\text { support }\end{array}$} & \multicolumn{4}{|c|}{ Support from supervisors } & \multicolumn{4}{|c|}{ Support from co-workers } & \multicolumn{4}{|c|}{ Job satisfaction } \\
\hline & $\begin{array}{l}6-3 \\
\text { points }\end{array}$ & 8-7 points & 9 points & $12-10$ points & $\begin{array}{l}5-3 \\
\text { points }\end{array}$ & 7-6 points & 8 points & 12-9 points & Satisfied & $\begin{array}{l}\text { Relatively } \\
\text { satisfied }\end{array}$ & $\begin{array}{l}\text { Somewhat } \\
\text { dissatisfied }\end{array}$ & Dissatisfied \\
\hline \multicolumn{13}{|l|}{ Men, $n=309$} \\
\hline $\begin{array}{l}\text { Number of } \\
\text { participants }\end{array}$ & 67 & 86 & 71 & 85 & 50 & 75 & 69 & 115 & 27 & 164 & 75 & 43 \\
\hline $\begin{array}{l}\text { Number of } \\
\text { participants } \\
\text { with<EQ-5D mean } \\
\text { value }\end{array}$ & 20 & 24 & 21 & 47 & 12 & 20 & 24 & 56 & 8 & 45 & 29 & 30 \\
\hline Age-adjusted OR & 1.00 & $\begin{array}{l}0.87 \\
(0.43 \text { to } 1.78)\end{array}$ & $\begin{array}{l}0.99 \\
\text { (0.48 to } 2.06)\end{array}$ & $\begin{array}{l}2.87 \\
(1.46 \text { to } 5.65)^{\dagger}\end{array}$ & 1.00 & $\begin{array}{l}1.08 \\
(0.47 \text { to } 2.50)\end{array}$ & $\begin{array}{l}1.57 \\
(0.68 \text { to } 3.61)\end{array}$ & $\begin{array}{l}2.91 \\
(1.37 \text { to } 6.14)^{\ddagger}\end{array}$ & 1.00 & $\begin{array}{l}0.87 \\
(0.35 \text { to } 2.13)\end{array}$ & $\begin{array}{l}1.44 \\
\text { (0.56 to } 3.73 \text { ) }\end{array}$ & $\begin{array}{l}5.56 \\
(1.94 \text { to } 15.98)^{\ddagger}\end{array}$ \\
\hline Model 1 OR & 1.00 & $\begin{array}{l}0.81 \\
(0.39 \text { to } 1.70)\end{array}$ & $\begin{array}{l}0.84 \\
\text { (0.39 to } 1.82)\end{array}$ & $\begin{array}{l}2.60 \\
(1.28 \text { to } 5.29)^{\dagger}\end{array}$ & 1.00 & $\begin{array}{l}1.03 \\
\text { (0.43 to } 2.45)\end{array}$ & $\begin{array}{l}1.45 \\
\text { (0.62 to } 3.42 \text { ) }\end{array}$ & $\begin{array}{l}2.70 \\
(1.24 \text { to } 5.90)^{*}\end{array}$ & 1.00 & $\begin{array}{l}0.78 \\
(0.31 \text { to } 1.96)\end{array}$ & $\begin{array}{l}1.25 \\
\text { (0.47 to } 3.34 \text { ) }\end{array}$ & $\begin{array}{l}5.09 \\
(1.70 \text { to } 15.25)^{\dagger}\end{array}$ \\
\hline $\begin{array}{c}\text { Model } 2 \text { OR } \\
\text { Women, } n=223\end{array}$ & 1.00 & $\begin{array}{l}0.61 \\
(0.27 \text { to } 1.36)\end{array}$ & $\begin{array}{l}0.66 \\
(0.29 \text { to } 1.51)\end{array}$ & $\begin{array}{l}1.43 \\
(0.65 \text { to } 3.12)\end{array}$ & 1.00 & $\begin{array}{l}0.87 \\
(0.34 \text { to } 2.24)\end{array}$ & $\begin{array}{l}1.10 \\
(0.44 \text { to } 2.75)\end{array}$ & $\begin{array}{l}1.48 \\
(0.63 \text { to } 3.47)\end{array}$ & 1.00 & $\begin{array}{l}0.74 \\
(0.28 \text { to } 1.99)\end{array}$ & $\begin{array}{l}0.71 \\
(0.24 \text { to } 2.10)\end{array}$ & $\begin{array}{l}2.09 \\
(0.62 \text { to } 7.09)\end{array}$ \\
\hline $\begin{array}{l}\text { Number of } \\
\text { participants }\end{array}$ & 48 & 66 & 41 & 68 & 50 & 68 & 25 & 80 & 22 & 120 & 59 & 22 \\
\hline $\begin{array}{l}\text { Number of } \\
\text { participants with } \\
<E Q-5 D \text { mean } \\
\text { value }\end{array}$ & 13 & 25 & 17 & 41 & 14 & 22 & 13 & 47 & 6 & 42 & 32 & 16 \\
\hline Age-adjusted OR & 1.00 & $\begin{array}{l}1.64 \\
(0.73 \text { to } 3.69)\end{array}$ & $\begin{array}{l}1.90 \\
(0.78 \text { to } 4.64)\end{array}$ & $\begin{array}{l}4.09 \\
(1.84 \text { to } 9.10)^{\ddagger}\end{array}$ & 1.00 & $\begin{array}{l}1.23 \\
(0.55 \text { to } 2.74)\end{array}$ & $\begin{array}{l}2.78 \\
(1.02 \text { to } 7.58)^{\star}\end{array}$ & $\begin{array}{l}3.66 \\
(1.71 \text { to } 7.84)^{\ddagger}\end{array}$ & 1.00 & $\begin{array}{l}1.44 \\
(0.52 \text { to } 3.95)\end{array}$ & $\begin{array}{l}3.15 \\
(1.08 \text { to } 9.19)^{*}\end{array}$ & $\begin{array}{l}7.24 \\
(1.90 \text { to } 27.55)^{\dagger}\end{array}$ \\
\hline Model 1 OR & 1.00 & $\begin{array}{l}1.63 \\
\text { (0.68 to } 3.92)\end{array}$ & $\begin{array}{l}1.71 \\
(0.67 \text { to } 4.35)\end{array}$ & $\begin{array}{l}3.95 \\
(1.69 \text { to } 9.22)^{\dagger}\end{array}$ & 1.00 & $\begin{array}{l}1.11 \\
(0.47 \text { to } 2.60)\end{array}$ & $\begin{array}{l}2.49 \\
(0.85 \text { to } 7.30)^{\star}\end{array}$ & $\begin{array}{l}3.45 \\
(1.55 \text { to } 7.66)^{\dagger}\end{array}$ & 1.00 & $\begin{array}{l}1.42 \\
(0.46 \text { to } 4.38)\end{array}$ & $\begin{array}{l}3.43 \\
(1.05 \text { to } 11.26)^{*}\end{array}$ & $\begin{array}{l}7.55 \\
(1.77 \text { to } 32.20)^{\dagger}\end{array}$ \\
\hline Model 2 OR & 1.00 & $\begin{array}{l}1.19 \\
(0.47 \text { to } 3.01)\end{array}$ & $\begin{array}{l}1.22 \\
(0.45 \text { to } 3.32)\end{array}$ & $\begin{array}{l}2.54 \\
(1.04 \text { to } 6.21)^{*}\end{array}$ & 1.00 & $\begin{array}{l}0.86 \\
(0.35 \text { to } 2.12)\end{array}$ & $\begin{array}{l}1.60 \\
(0.51 \text { to } 5.05)\end{array}$ & $\begin{array}{l}2.59 \\
(1.12 \text { to } 5.97)^{\star}\end{array}$ & 1.00 & $\begin{array}{l}1.36 \\
(0.42 \text { to } 4.38)\end{array}$ & $\begin{array}{l}2.06 \\
\text { (0.58 to } 7.28)\end{array}$ & $\begin{array}{l}3.49 \\
(0.74 \text { to } 16.36)\end{array}$ \\
\hline \multicolumn{13}{|l|}{ Total, $n=532$} \\
\hline $\begin{array}{l}\text { Number of } \\
\text { participants }\end{array}$ & 115 & 152 & 112 & 153 & 100 & 143 & 94 & 195 & 49 & 284 & 134 & 65 \\
\hline $\begin{array}{l}\text { Number of } \\
\text { participants with } \\
<E Q-5 D \text { mean } \\
\text { value }\end{array}$ & 33 & 49 & 38 & 88 & 26 & 42 & 37 & 103 & 14 & 87 & 61 & 46 \\
\hline
\end{tabular}




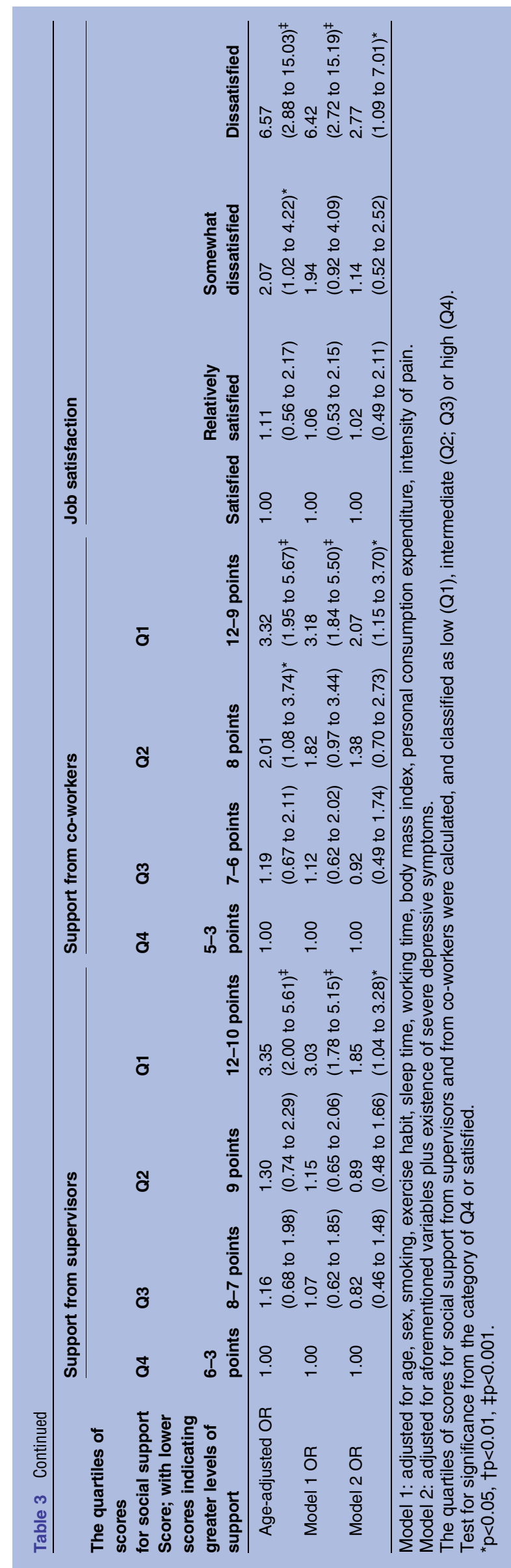

intensity of migraine was correlated with EQ-5D. ${ }^{23}$ Patients with chronic pain reporting poor support in the workplace showed a higher prevalence of low mean EQ-5D, indicating that these work-related psychosocial factors are important for maintenance of general health status and functional well-being.

Absence from work because of sickness for regional pain symptoms is much less common in Japan compared with that in the UK. ${ }^{24}$ Compared with the UK, the reported rates of sick leave for regional pain symptoms in Japan are less than one-third (only 5\%). ${ }^{24}{ }^{25}$ According to the population-based survey, ${ }^{26}$ the prevalence of chronic pain in Japan $(22.9 \%)$ is similar to that in Europe; ${ }^{2}$ therefore, the number of people who are working with chronic pain without absence from work may be larger in Japan than in the UK. This cultural difference may reflect the result of a wide range HRQoL of workers with chronic pain being observed in the present study; thus, the association between work-related psychosocial factors and EQ-5D among workers with chronic pain may be detected sensitively in the current Japanese study.

Depression is strongly associated with psychosocial factors, chronic pain and QoL in the clinical setting. ${ }^{14}$ The lifetime prevalence of major depression in primary care settings is $5-10 \%,{ }^{27}$ and the reported prevalence of pain in patients with depression averages about $65 \%$ (range 15-100\%). ${ }^{28}$ The estimated coexistence of major depression with chronic pain in the general population is $18 \%(4.7-22 \%) .^{28}$ In fact, the presence of severe depressive symptoms was the most powerful confounder in our study.

\section{Limitations}

There are several limitations to our study. First, the participants may not be truly representative of the general population. Although the demographic profile of respondents was consistent with the Japanese demographic composition for sex and age in 2007, the 1764 participants who answered the detailed questionnaire were selected purposefully (by eliminating those with acute and subacute pain). According to the Annual Report on the Labor Force Survey in $2009,{ }^{29}$ the percentage of the Japanese labour force aged 20-59 years was $92.5 \%$ for men and $69.9 \%$ for women, while $88.5 \%$ of male respondents and $52.2 \%$ of female respondents were currently in the labour force. The proportions of job categories were biased. Specialists and white-collar workers have a majority $(57.7 \%)$, and the proportion of primary sector workers was very low $(0.6 \%)$. Moreover, factors influencing the decision to respond to the webbased survey may have biased the distribution. For example, it may have selected against extremely busy workers or older workers less familiar with the internet. In addition, the respondents may have been particularly interested in pain research, possible due to personal affliction. The sampling issues of the web-based survey were noted before. ${ }^{30}$ This difference, particularly the 
low portion of female respondents in the workforce, could have influenced the results.

Second, our questionnaire included only three psychosocial factors, social support from supervisors, support from co-workers and job satisfaction. 'Job demand' and 'job control" ${ }^{31}$ have also been included as work-related psychosocial factors, but these were not examined in this study. Our questionnaire did not include social support in private life. Furthermore, individual psychosocial factors such as 'fear avoidance', 'pain catastrophising' and 'resilience' were not investigated in the present study.

Third, patients with severe chronic pain who took sick leave or had retired due to pain were not included in our study. This limitation could reduce the statistical power to examine the association between work-related psychosocial factors and chronic pain.

\section{CONCLUSION}

Male workers reporting job dissatisfaction had a higher prevalence of chronic pain than those reporting job satisfaction. Among workers with chronic pain, those reporting poor social support and job dissatisfaction had a greater frequency of low HRQoL. Thus, work-related psychosocial factors are critical influences on the HRQoL of workers with chronic pain.

Acknowledgements The authors express their appreciation to Yasuo Takagi, professor of Keio University, Japan, for his valuable help in conducting the survey. The authors are grateful to all of the participants of this study. The authors thank Nagisa Mori for her linguistic advice. The authors would like to thank Enago (http://www.enago.jp) for the English language review.

Contributors KY conceived the original idea for the study, performed the analyses of the data and drafted the manuscript. KM and HI revised the manuscript, contributed to the interpretation of the data and added critical comments. $\mathrm{HI}$ and $\mathrm{AK}$ revised the manuscript and contributed with comments. All the authors approved the final version.

Funding This research received no specific grant from any funding agency in the public, commercial or not-for-profit sectors.

Competing interests None declared.

Patient consent Obtained.

Ethics approval The Institutional Review Boards of Keio University and of the Japan Labour Health and Welfare Organization.

Provenance and peer review Not commissioned; externally peer reviewed.

Data sharing statement No additional data are available.

Open Access This is an Open Access article distributed in accordance with the Creative Commons Attribution Non Commercial (CC BY-NC 4.0) license, which permits others to distribute, remix, adapt, build upon this work noncommercially, and license their derivative works on different terms, provided the original work is properly cited and the use is non-commercial. See: http:// creativecommons.org/licenses/by-nc/4.0/

\section{REFERENCES}

1. Goldberg DS, McGee SJ. Pain as a global public health priority. BMC Public Health 2011;11:770.

2. Croft P, Blyth FM, van der Windt D. Chronic pain epidemiology: from aetiology to public health. 1st edn. USA: Oxford University Press.

3. Waddell G, O'Connor M, Boorman S, et al. Working Backs Scotland: a public and professional health education campaign for back pain Spine 2007;32:2139-43.
4. Rüesch P, Graf J, Meyer PC, et al. Occupation, social support and quality of life in persons with schizophrenic or affective disorders. Soc Psychiatry Psychiatr Epidemiol 2004;39:686-94.

5. Linton SJ. Occupational psychological factors increase the risk for back pain: a systematic review. J Occup Rehabil 2001;11: 53-66.

6. Hoogendoorn WE, van Poppel MN, Bongers PM, et al. Systematic review of psychosocial factors at work and private life as risk factors for back pain. Spine 2000;25:2114-25.

7. Palmer KT, Calnan M, Wainwright D, et al. Disabling musculoskeletal pain and its relation to somatization: a community-based postal survey. Occup Med (Chic III) 2005;55:612-17.

8. Brouwer WBF, Meerding WJ, Lamers LM, et al. The relationship between productivity and health-related QOL: an exploration. Pharmacoeconomics 2005;23:209-18.

9. Yamada K, Matsudaira K, Takeshita K, et al. Prevalence of low back pain as the primary pain site and factors associated with low health-related quality of life in a large Japanese population: a pain-associated cross-sectional epidemiological survey. Mod Rheumatol 2013

10. Japanese Ministry of Internal Affairs and Communications. http:// www.stat.go.jp/data/jinsui/2007np/index.htm (accessed 14 Mar 2015).

11. Rakuten Research: English. http://research.rakuten.co.jp/en/ (accessed 14 Mar 2015)

12. Shimomitsu T, Haratani T, Nakamura K, et al. The final development of the Brief Job Stress Questionnaire mainly used for assessment of the individuals. Tokyo, 1990.

13. Williams A. EuroQol-a new facility for the measurement of health-related quality of life. Health Policy (New York) 1990;16:199-208.

14. Dworkin RH, Gitlin MJ. Clinical aspects of depression in chronic pain patients. Clin J Pain 1991;7:79-94.

15. Yamazaki S, Fukuhara S, Green J. Usefulness of five-item and three-item Mental Health Inventories to screen for depressive symptoms in the general population of Japan. Health Qual Life Outcomes 2005;3:48.

16. Fukuhara S, Bito S, Green J, et al. Translation, adaptation, and validation of the SF-36 Health Survey for use in Japan. J Clin Epidemiol 1998;51:1037-44.

17. Woodrow KM, Friedman GD, Siegelaub AB, et al. Pain tolerance: differences according to age, sex and race. Psychosom Med 1972;34:548-56.

18. Craft RM, Mogil JS, Aloisi AM. Sex differences in pain and analgesia: the role of gonadal hormones. Eur J Pain 2004;8:397-411.

19. Ministry of Internal Affairs and Communications. Survey on time use and leisure activities (in Japanese). 2011. http://www.stat.go.jp/data/ shakai/2011/pdf/houdou2.pdf (accessed 2 Jun 2015).

20. Friborg $\mathrm{O}$, Hjemdal $\mathrm{O}$, Rosenvinge $\mathrm{JH}$, et al. Resilience as a moderator of pain and stress. J Psychosom Res 2006;61:213-19.

21. Saarni SI, Härkänen T, Sintonen $\mathrm{H}$, et al. The impact of 29 chronic conditions on health-related quality of life: a general population survey in Finland using 15D and EQ-5D. Qual Life Res 2006;15:1403-14.

22. Payakachat N, Ali MM, Tilford JM. Can the EQ-5D detect meaningfu change? A systematic review. Pharmacoeconomics 2015;33:1137-54.

23. Xu R, Insinga RP, Golden W, et al. EuroQol (EQ-5D) health utility scores for patients with migraine. Qual Life Res 2011;20:601-8.

24. Matsudaira K, Palmer KT, Reading I, et al. Prevalence and correlates of regional pain and associated disability in Japanese workers. Occup Environ Med 2011;68:191-6.

25. Madan I, Reading I, Palmer KT, et al. Cultural differences in musculoskeletal symptoms and disability. Int J Epidemiol 2008;37:1181-9.

26. Matsudaira K, Tatsuya I. Epidemiological findings from our studies of musculoskeletal pain. Pain Clin 2013:34:S53-61.

27. Katon W, Schulberg H. Epidemiology of depression in primary care. Gen Hosp Psychiatry 1992;14:237-47.

28. Bair MJ, Robinson RL, Katon W, et al. Depression and pain comorbidity: a literature review. Arch Intern Med 2003;163:2433-45.

29. Annual Report on the Labor Force Survey (in Japanese). http://www. stat.go.jp/data/roudou/report/2009/ (accessed 14 Mar 2015).

30. Rhodes SD, Bowie DA, Hergenrather KC. Collecting behavioural data using the world wide web: considerations for researchers. J Epidemiol Community Health 2003;57:68-73.

31. De Jonge J, Van Vegchel N, Shimazu A, et al. A longitudinal test of the demand-control model using specific job demands and specific job control. Int J Behav Med 2010;17:125-33. 